\title{
Phenotypic Plasticity as a Strategy of Bacterial Resistance and an Object or Advanced Antimicrobial Technologies (Review)
}

DOI: $10.17691 / \mathrm{stm} 2019.11 .2 .22$

ReceivedMay 25, 2018

B.G. Andryukov, MD, DSc, Leading Researcher, Laboratory of Molecular Microbiology'; Professor, Department of Fundamental Sciences';

L.M. Somova, MD, DSc, Professor, Chief Researcher, Laboratory of Molecular Microbiology';

E.N. Matosova, Junior Researcher, Laboratory of Molecular Microbiology';

1.N. Lyapun, PhD, Researcher, Laboratory of Molecular Microbiology'

ISomov Institute of Epidemiology and Microbiology, 1 Selskaya St., Vladivostok, 690087, Russia;

2Far Eastern Federal University, 8 Sukhanova St., Vladivostok, Russia

Adaptation to continuously changing habitat is one of the most important characteristics of microorganisms. A particularly effective form of adaptation is called phenotypic plasticity. This ability allows bacteria with a stable genotype to create different phenotypes in response to environmental changes. Such variability is not inheritable but is crucial for maintaining this specific bacterial population and, even more, for developing resistanc

e to antibiotics. Studying the phenotypic plasticity, which underlies the resistance of microorganisms to traditional antibiotic therapy, is a key area of the current antimicrobial technologies. In this review, phenotypic plasticity is considered to be a strategy of bacterial survival and a mechanism for developing antibiotic resistance in dormant (resistant) cellular forms of bacteria. We suggest that studying the phenotypic variants of bacteria (L-forms; viable but nonculturable bacteria; persister cells) will result in the development of novel effective antimicrobial technologies.

Key words: bacteria adaptation; habitat; phenotypic plasticity; L-forms; viable but nonculturable bacteria; VBNC; persister cells; advanced antimicrobial technologies.

\section{Introduction}

Bacterial infections are among major causes of morbidity and mortality. In almost all countries, regardless of their economic development, we evidence an increase in infectious diseases characterized by latent, prolonged and chronic clinical forms [1, 2]. The incidence rates of infections associated with opportunistic flora and with intra-hospital sources are also on the rise. Often, the traditional antibiotic therapy is powerless against the advancing drug resistance of pathogens; the problem is defined by the WHO as one of the most serious challenges of public health [3].

The development of new drugs or improvement of existing antibiotics is becoming an increasingly long and complicated process and, in some cases, economically unaffordable. To find alternative antibacterial strategies, a number of innovative approaches have been tried. One of these pertains to the phenotypic plasticity of bacteria; this quality of bacterial cells underlies their adaptation potentials and their resistance to antibiotics.

Recent achievements of molecular biology and genetics expanded the understanding of the adaptation, regulation, forms of existence, and epidemiological role of pathogenic bacteria in the infectious process [4-6]. The widespread and uncontrolled use of antibacterial drugs over the past decades without considering the specific response of microorganisms has led to the decline of the antibiotic era and necessitate a search for alternative therapeutic strategies able to overcome the drug resistance of bacteria $[3,7]$.

Environmental conditions are constantly changing, and in order to preserve viability and adaptability, many bacteria have developed various mechanisms for switching to a metabolically inactive state $[1,4,5]$. The most studied type of cellular dormancy is sporulation, which is characteristic of sporogenous bacteria [2]. However, in recent years, due to the progressive decline in the efficacy of traditional antibiotics, sustainable cellular forms of non-sporogenous bacteria have attracted more and more research interest $[1,2,4]$.

Among the main factors of antibiotic resistance and the resulting spread of chronic infections, there is the so-called non-genetic phenotypic heteromorphism, i.e., the transformation into resistant (dormant) cell forms that do not necessarily meet the generally accepted taxonomic criteria. Such (morphologically and physiologically) atypical cells exist in the state of metabolic and reproductive dormancy, due to which they are inaccessible to routine microbiological diagnosis and insensitive to most antibacterial agents [6, 8-10].

Corresponding author: Boris G. Andryukov, e-mail: andrukov_bg@mail.ru 
According to the currently accepted views, a bacterial population is defined as a variety of heteromorphic microorganisms of a single species that freely develop in a given ecosystem and that are capable of accumulating its biomass with no limits [6,11, 12]. These bacterial communities can trigger the adaptation mechanisms to resist a continuously changing habitat, which is reflected in the phenotypical diversity of bacterial cell morphology $[9,10]$.

Thanks to electron microscopy, it was possible to establish the heterogeneity of the morphological structure of homogeneous microbial populations, i.e., a unified system of interconnected cell forms with different ultrastructures and organizations that remain viable under changing environmental conditions. As concluded from numerous studies, bacterial cells continue to permanently adapt thanks to their polymorphic plasticity $[5,9,10,13,14]$.

A long-term study by one of us (Somova [15]) on ultrastructural changes in bacteria and polymorphism of periodic cultures of gram-negative Yersinia pseudotuberculosis and gram-positive Listeria monocytogenes suggests that the phenotypic morphological transformation in bacteria is a universal mechanism of adaptation to adverse environmental factors. Based on the obtained results, we propose to systematize ultrastructural changes of pathogenic bacteria considering this biological concept.

A surge in scientific interest in dormant forms of bacteria was triggered by the discovery of toxin-antitoxin systems (TAS); those are thought to be a general mechanism of genetic control over of the formation of dormant bacteria [1, 2]. The increasing problem of drugresistant bacteria makes this type of research more and more relevant [16-20].

In this review, we address the phenotypic plasticity as a strategy for survival and for development of antibiotic resistance in dormant (resistant) cellular forms of bacteria.

\section{Dormant (resistant) cell forms, the persistence of bacteria}

One of the main criteria of bacterial cell viability is the coordinated reproduction of all cellular components and structures during cultivation. The last century discovery of anabiotic persistent forms of bacteria has expanded the traditional understanding of prokaryotic survival abilities $[9,10,21,22]$.

The de novo formation of resistant forms of bacteria is a response to adverse factors including the exposure to antibiotics. Biological expediency of these processes can be explained by the need to preserve the population of these microorganisms. According to recent data $[9,10,23]$, most chronic and intra-hospital infections, autoimmune, lymphoproliferative and neoplastic diseases are caused by atypical bacterial cells that are resistant to traditional antibacterial agents and successfully evade attacks by the immune defense system.

These dormant cell forms are characterized not only by phenotypic heteromorphism but also by poor or zero growth in regular nutrient media, which makes their identification and bacteriological classification difficult. For decades, these forms were found in microscopic preparations, but most of them were ignored or interpreted as artifacts $[9,13,24,25]$.

Phenotypic adaptation of bacteria caused by adverse chemical-physical factors of the environment is not limited only to morphological changes, but also includes functional rearrangements in bacterial cells. Subpopulations of atypical cells are characterized by reduced growth rates and low metabolic activity; under optimal conditions, though, they can rapidly restore their original morphology and function (so-called, the reversion process). Therefore, resistance to antibacterial drugs in aberrant cellular forms is associated with the formation of transient (phenotypic) resistance sensitivity to antibiotics is restored after the reversion [9, $13,14,24]$.

In this respect, a bacterial population can be considered as a dynamic self-controlled, constantly changing heteromorphic and polyfunctional multicellular system, which has a high adaptive potential aimed at preserving the species $[9,25,26]$.

The widespread use of antibacterial drugs significantly changed the clinical picture of some infections and even distorted the results of microbiological analyses [2629]. These changes stimulated the research into the role of metabolic changes and atypical morphological characteristics of microorganisms in the pathogenesis infectious diseases [24, 27, 29].

Manifestations of phenotypic morphological plasticity in non-sporogenous microorganisms (described in the $\mathrm{XX}$ century) included forms resistant to traditional antibiotic therapy: L-forms (L-transformation, cell wall deficient bacteria, CWD) [30], viable but nonculturable bacteria (VBNC) [31], and persister cells [32], collectively termed the "bacterial cell persistence" [33-35].

From the standpoint of currently available knowledge, it is rather difficult to draw a line between the two physiological states of bacteria - the cellular dormancy of non-replicating bacteria and the cell persistence; the second term has a broader meaning and includes various physiological states of bacteria, one of which is the unique biology of L-forms.

L-form (L-transformation) of bacteria. L-forms (bacteria with a defect in the cell wall) have been known to microbiologists for a long time. In the 1970-80s, this morphological transformation of microorganisms was actively studied all over the world. The current surge of scientific interest in L-forms has been motivated by the emergence of new methods of molecular genetic research and also by the increasing global concern about the worsening problem of bacterial drug resistance [36-38]. 
In addition to determining the role of L-forms in the etiology of protracted and chronic infections in humans and animals, the current research efforts are aimed at studying the mechanisms of their resistance. Special attention is given to the L-bacteria circulating in the blood and also to the potentially dangerous uncontrolled colonization of morphologically atypical microbial cells (including those emerged after prophylactic vaccination) [39-43]. The very paradigm of the L-form existence calls into question the validity of the current concepts and some of the classical postulates of clinical microbiology [39-41, 43].

One of these concepts is associated with the key role of the cell wall $(\mathrm{CW})$ in the bacteria life cycle and, in particular, the role of $\mathrm{CW}$ in the binary division. The existence of the outer membrane was the basis for the traditional separation of bacteria into gram-positive (two-layer) and gram-negative (three-layer) types. The supporting component of the CW specific for bacterial cells (except for Tenericutes and related mycoplasmas that naturally lack CW) is the biopolymer layer. In grampositive bacteria, this layer is thicker; it consists of peptidoglycan - a mesh of glycan threads and peptide bridges $[40,44,45]$.

In addition to actively participating in the division, this elastic cellular structure determines the shape of bacteria, ensuring the maintenance of intracellular pressure. The peptidoglycan layer, which is part of the bacterial $\mathrm{CW}$, is a recognized target for $\beta$-lactam, glycopeptide and lipopeptide antibiotics that block the $\mathrm{CW}$ synthesis. In addition, fragments of the $\mathrm{CW}$ are recognized by human immune receptors, causing a powerful protective response of the body against the infection [27, 38, 45, 46].

Under adverse conditions, many bacterial species are able to turn into a state characterized by the loss of the peptidoglycan layer and the absence (deficiency) of the CW, called the L-form; this is considered an extreme form of life and one of the bacteria survival tools [28, 39, 40]. Antibiotics (mostly, penicillin), antimicrobial factors of the body (primarily, lysozyme), and other intrinsic effectors (for example, enzymes, immunoglobulins, and other immune factors) as well as some physicochemical conditions (acids, alkalis, ultraviolet radiation) can act as transforming factors [14, 27, 44, 45, 47].

The absence of CW allows the L-forms to avoid the effects of (the recently discovered) endogenous peptidoglycan recognition proteins (PGRP), which are a family of four evolutionary-conservative antibacterial effectors of the innate immune system [48].

The name "L-form" was proposed in 1935 by Emmy Klieneberger-Nobel in honor of the Lister Institute of Preventive Medicine, in which she was then studying mycoplasmas [30]. During the study, she found that the temporary loss of CW was a common strategy of adaptation to adverse living conditions in most grampositive and gram-negative bacteria. Such a strategy contributes to the preservation of the species; the obligate existence inside the host provides bacteria with favorable osmotic conditions [36, 46, 49, 50].

Subsequently, the term "L-form" was used to characterize a type of bacterial cells isolated from humans, animals, and plants that lack a rigid CW and have the ability to switch between two morphological forms - classical and heteromorphic [14]. After the discovery of L-forms, concepts similar in meaning were adopted: e.g., L-phase (L-phase bacteria), L-variants, L-organisms, the forms with a CW defect, CWD-forms and others [1, 26, 51-54]. A wide variety of descriptions and characteristics of these cellular forms and their stages caused some terminological uncertainty $[1,5,7]$.

Currently, the term CWD bacteria is the most commonly used in the literature, covering spheroid, protoplasts (incapable of division) and the L-forms themselves (capable of indefinite division). At the same time, phenotypic variants of bacteria with reversible (unstable L-form) and irreversible (stable L-form) changes in the $\mathrm{CW}$ organization are viewed as separate categories [5, 14]. Irreversible changes are due to genomic mutations.

The unique morphology of L-forms of bacteria, the mechanisms of their formation and the etiopathogenetic role in chronic infections have been objects of numerous scientific studies for a long time [6, 8, 34].

Stable L-forms have become a useful model for studying the proliferation of bacterial cells, the main biological functions of membranes, and the ability of CWD to cause chronic infections [8, 34]. Unstable L-forms are actively used to study the molecular mechanisms of their formation and the survival of bacteria under physiological conditions $[8,34,36,49]$.

The main stages and types of morphological transformation of L-forms and L-like forms in bacterial populations are described in detail. Attempts have been made to classify and systematize numerous ultrastructural changes of these cells and their functional features using the well-studied transformations of $\mathrm{CW}$-deficient microorganisms $[21,27,28]$. This systematization is based primarily on morphological indices (integrity of the cell membrane) and the ability of CWD-forms to reproduce and reverse in special culture conditions $[4,5,14,45]$.

L-forms of bacteria do not grow in regular nutrient media, but they can be cultured in serum-rich elective media containing CW inhibitors (antibiotics), osmoprotectors (glucose, sodium chloride), and growth stimulants (magnesium, zinc). They do not stain by Gram, are not agglutinated with antisera and are not lysed by phages [27, 28].

Bacteria with the traditional structure of cell walls multiply by binary division mediated by the key cytoskeletal proteins - MreB and FtsZ, which are functional analogues of actin and tubulin, respectively $[14,21,28,38,55]$.

The proliferation of CWD bacteria occurs through a different mechanism. It is known that a change in the 
environment causes their cytoplasmic membranes to get transformed; this process is determined by the qualitative and quantitative characteristics of the lipid bilayer, specifically, by the amounts of unsaturated and polyunsaturated fatty acids, as well as the length of the acyl chains and their branching [56, 57]. Mercier et al. [46] proposed that the high fluidity of cytoplasmic membranes played a leading role in the L-form reproduction process. Mutant bacterial cells with a low membrane fluidity, when in the L-transformed state, can increase in size but are incapable of entering the final phase of proliferation (rupture of the membrane) needed to generate daughter cells $[14,28,46]$.
Thus, using the currently accepted model of L-form proliferation, one can trace the evolution of early forms of cell life on Earth by reconstructing the primitive mechanism of cell division up to the appearance of a $\mathrm{CW}$, nucleic acid encapsulation, and horizontal gene transfer [36, 49].

Colonies of L-forms resulted from the proliferation process are heteromorphic cell populations consisting of large masses, filamentous and tubular structures, elementary bodies and spherical cells of various sizes with an uneven vacuolated cytoplasm and fragments of the cytoplasmic membrane (Figure 1). In the process of subsequent development, morphological transformation

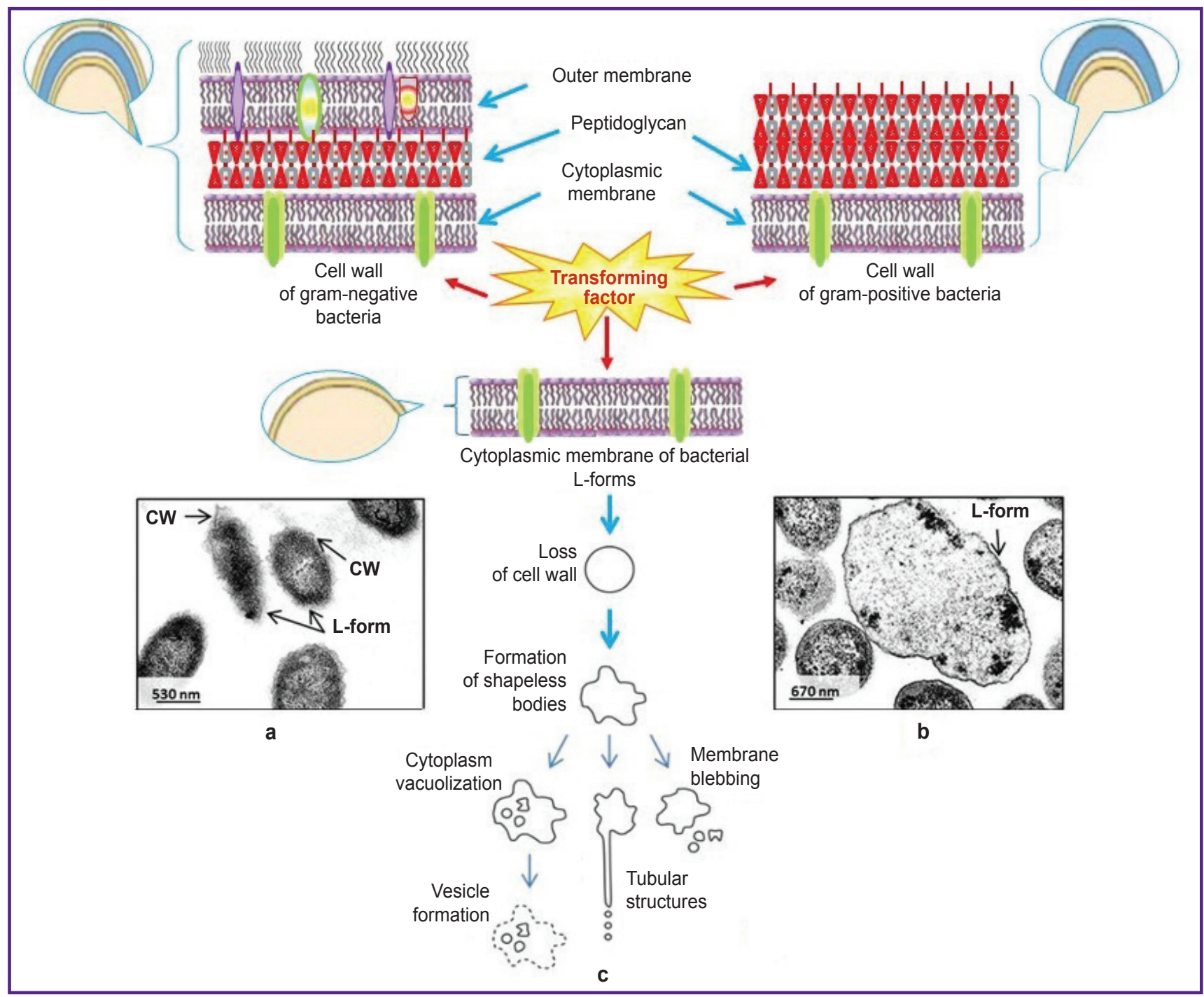

Figure 1. Formation and proliferation of bacterial L-forms

Formation of L-forms resulted from the loss of the peptidoglycan layer: (a) periodic culture (Y. pseudotuberculosis, strain $\mathrm{H}-2781$ ), phosphate-buffered saline, $37^{\circ} \mathrm{C}$, L-form bacteria - spheroplasts; (b) periodic culture (Y. pseudotuberculosis, strain $\mathrm{H}-2781$ ), phosphate-buffered saline, $6-8^{\circ} \mathrm{C}$, L-form bacteria - protoplasts; (a), (b) transmission electron microscopy by JEM-100 S (JEOL, Japan). The three-layer cell wall (CW) of gram-negative and the bilayer $\mathrm{CW}$ of gram-positive bacteria lose the peptidoglycan layer because of the transforming factor: (c) various structural elements of the L-form reproduction: large bodies, filamentary and tubular structures, elementary bodies and spherical cells of different sizes with a rough and interrupted cytoplasmic membrane and vacuolated cytoplasm. Authors' depiction; photo by Somova 
of bacterial elements occurs, their virulence decreases, energy requirements and metabolism slow down, thus allowing them to survive inside the body and later restore the original virulence during in vivo reversion [14, 28, $36,46]$.

In recent years, increased attention has been paid to the interaction between stable L-form bacteria and blood phagocytes - immunocompetent cells capable of capturing foreign particles, including bacteria and viruses. Thus, a group from Bulgaria isolated CWD-forms of Mycobacterium bovis from 141 samples of human blood taken after preventive vaccination for tuberculosis $[39,41,43]$. The polymorphism of these populations and the staging of their transformation were found typical for L-forms; accordingly, the authors concluded that CWD cells were not only able to survive, but also to multiply in human blood cells, where they stayed unidentified due to their genomic and morphological transformations [40, 41, 43].

Since the discovery of L-forms of pathogens, evidence has been obtained of the possibility of their long time existence in the body and the etiological connection of these forms with a wide range of infectious diseases [1, $8,34,58]$. Most studies have focused on the role of CWD bacteria in the development of persistent and recurrent chronic infections of the urinary tract, cardiovascular and central nervous systems, which are characterized by alternating remissions and exacerbations (tuberculosis, pyelonephritis, septic endocarditis, scleroderma, brucellosis) [2, 10, 14, 59]. Cases of idiopathic chronic inflammatory, collagen-associated, lymphoproliferative, nephro-urological (including interstitial nephritis and prostatic neuralgia) and neoplastic diseases associated with L-forms have been described [1, 8, 9, 39, 60].

Thus, Han et al. [61] showed that the causative agent of sepsis and pneumonia - methicillin-resistant Staphylococcus aureus - is able to convert to L-forms in addition to its natural genotypic resistance to antibiotics.

The most frequent localizations of infectious processes in the urinary organs have a physiological basis. It is associated with tissue specifics of the kidney medulla, in which juxtamedullary nephrons create the high osmotic pressure necessary for the formation of the final urine. This osmotic environment favors the existence of antibiotic-resistant L-forms of bacteria and the development of persistent and smoldering infections. In addition, in patients with bacterial infections of the bladder and kidneys, the urine osmolarity is often abnormally high, especially if associated with carbohydrate metabolism disorders [38, 46, 59].

The question of preserving the initial virulence in bacteria at the L-transformed stage remains debatable. However, even with a decrease in their virulence, CWD forms can create a reservoir of pathogens hidden from the immune system and resistant to antibiotics [13, 24]. Cells with a CW defect, in contrast to persister cells, do not lose the ability to multiply and can restore their virulence inside macrophages [39, 40].
Despite the clinical importance of CWD cells and the relevant long-time studies, little is currently known about the molecular mechanisms involved in the existence and survival of these morphologically aberrant forms $[28,38]$. Recent studies have shown that the L-forms of L. monocytogenes are not only morphologically different from the mother cells but also have reversible functional changes at the genetic and molecular levels [58].

Kawai et al. [27] found that for the L-transformation of Bacillus subtilis, two types of genetic mutations are needed; those are able to prevent the damaging effects of reactive oxygen species produced in bacterial cells during the active life cycle. The authors concluded that the formation of CW-deficient cells is limited by the presence of free radicals and, therefore, antioxidants can stimulate the phenotypic generation of L-forms in both gram-positive and gram-negative bacteria. Mutation of the ispA gene (type 2) stabilizes the structural elements of the L-form proliferation and prevents their lysis.

Unlike other resistant bacterial forms, CWD bacteria remain viable and can multiply in the presence of antimicrobial agents. Upon stopping the treatment, these cells can return to their original morphology and restore their virulence, leading to a return of the disease [8, 21, 38].

Because of their pleomorphism and high plasticity of cells, CWD bacteria can penetrate and remain in physiological niches that are inaccessible to the maternal forms. Resistance of L-forms to traditional antibiotic therapy, as well as their ability to restore the original morphology and virulence, results in the development of persistent and protracted infections, and substantially complicates the treatment of the elderly or patients with weakened immunity $[5,21,38]$.

Thus, the existence of bacterial L-forms represents a sophisticated mechanism of bacterial resistance to antibiotics [22, 29]. Although this form of survival is common to almost all known pathogenic bacteria, so far we have got only a fragmentary picture of the interaction between the L-forms and the human body.

Bacteria L-forms as an object of medical technologies. Despite the long history of studying the L-forms, their accidental detection in blood is most often regarded as an artifact that has no diagnostic value [62]. The lack of convincing etiological attribution of bacteria L-forms to any group of infections is due to the difficulties of cultivating and identifying these cellular forms, which might be associated with their phenotypic plasticity.

Among the urgent questions to be answered is whether CWD bacterial cells can be part of the normal blood microbiota. Of particular interest is the understanding of biological significance of this phenomenon, as well as the development of new microbiological methods for isolating these nonculturable forms from the blood.

In 2015, Markova et al. [40] proposed an innovative method of multistage isolation of L-forms from human 
blood with subsequent morphological identification using light microscopy (the "blind passage" method) [40]. Detection of microbial DNA and electron microscopy visualization of L-cells suggests that they are (least to say) frequent members of the blood microbiota [41]. Reports of long-term persistence of bacteria L-forms on the surface or inside macrophages [63], erythrocytes $[42,43]$, and platelets [64] laid the ground for the hypotheses about their possible role as causative agents of infectious diseases in humans $[41,65,66]$.

These hypotheses have gained support from the recently discovered existence of L-forms of Bacillus spp. and Micrococcus spp. in the blood of healthy people and their ability of vertical transmission through the placental barrier [42].

Other stable forms of bacteria - persister cells and viable but nonculturable microorganisms closely adjoin the L-forms. These cellular forms are also formed in response to adverse environmental conditions and represent phenotypic variants of the bacterial adaptation strategies.

Persister cells. The phenomenon of persistent bacterial cells was discovered in the middle of the last century by Hobby et al. [32], who reported the survival of a small part of the $S$. aureus population after complete sterilization of a bacterial culture with penicillin. Later, this part of the bacterial population was named persister cells ("inactive, non-dividing variants") [67]. It was then found that inhibiting the growth of $S$. aureus by lowering the incubation temperature, removing nutrients or adding boric acid increases the proportion of persister cells $[32,68]$.

The phenomenon of bacterial persistence has been studied in detail [1,69-74]. Specifically, it is found that persister cells usually make up only a small fraction of the bacterial population. In wild-type E. coli strains, their occurrence in plankton cultures amounts to no more than one per million cells $[72,75,76]$. However, in biofilms complex multicellular bacterial communities that are highly resistant to antibiotics and are responsible for more than $80 \%$ of human infections - their presence is significantly higher: up to one hundred bacteria per million $[72,77,78]$.

The mechanism of the transient antibiotic resistance of persister cells is associated with the resting state of their replication and metabolism [1, 67, 73, 74]. Most antibiotics act by suppressing the vital processes in metabolically active and growing cells; the more active these processes, the more effective are the drugs. In this respect, persistence is the occurrence of spontaneous phenotypic variants in isogenic bacterial populations; these variants are resistant to antibiotics [67, 75-78].

The presence of persistent cells in a bacterial culture is biologically significant because these cells may cause chronic and nosocomial infections, including those associated with the causative agents of sapronoses (purulent septic infections, pneumonia, intestinal infections, tetanus, gas gangrene et al.) $[74,79,80]$.
In the current literature, persister cells are defined as resting and irregular subpopulations that are present in a growing bacterial culture and are resistant to several antibiotics, antiseptics, and disinfectants $[29,67,77,79$, 81]. Their fundamental difference from antibiotic-resistant mutant bacteria is that the persister cell population is not capable of multiplication, and their tolerant phenotype is preserved only at rest and is, therefore, not inherited [60, 76-78].

It would seem that the phenotypic antibiotic resistance in persister cells is associated exclusively with the state of metabolic and replicative dormancy. However, recent studies have revealed some physiological heterogeneity of persistent cells and varying degrees of their resistance to antibiotics [68, 69, 72, 82]. In an experiment, selective inhibition of bacterial replication leads to antibiotic resistance only when it is accompanied by an active cell response to stress [83]. Other reports [68, 73, 84] indicate that suppression of the metabolic activity only does not prevent the death of $99 \%$ of the bacterial population treated with antibacterial agents.

In studies of Balaban et al. [60], Maisonneuve et al. [85], and Van den Bergh et al. [86], a phenotypic population of individual (up to 1\%) persister cells is present in most bacterial cultures that are in the stationary phase of growth and in the absence of antibiotics or stress. In the process of the vital activity, vegetative (active) bacterial cells can form a persistent phenotype and vice versa; the pace of these reversions depends on the growth phases and environmental conditions (Figure 2).

Therefore, the formation of persister cells is not associated exclusively with the influence of antibacterial agents. The presence of these cells protects the population from death under sudden and massive antibiotic therapy, which gives a competitive advantage to microorganisms in the periodically changing habitat [73, 83, 87, 88].

Bacteria reaction to various environmental stimuli is mediated by genetically determined mechanisms that convert external signals into changes in the intracellular concentration of secondary inducers (cAMP, c-di-GMP,

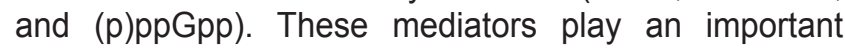
role in maintaining cell viability, inter- and intra-cellular communications, which allow bacteria not only to react to environmental stressors but also to modulate their virulence (e.g., adhesion, biofilm formation, etc.) and ultimately - all stages of the infectious process $[82,89]$.

The key factors of bacterial stress-resistance are the signaling intracellular nucleotides - (p)ppGpp: guanosine tetraphosphate (ppGpp) and guanosine pentaphosphate (pppGpp) [90-92]. These secondary mediators have their intracellular concentrations increased when exposed to environmental challenge; in addition, they actively participate in the so-called "strict response" [90, 93]. They are able to reprogram a number of processes, including the expression of genes involved in amino acid biosynthesis, bacterial virulence, 


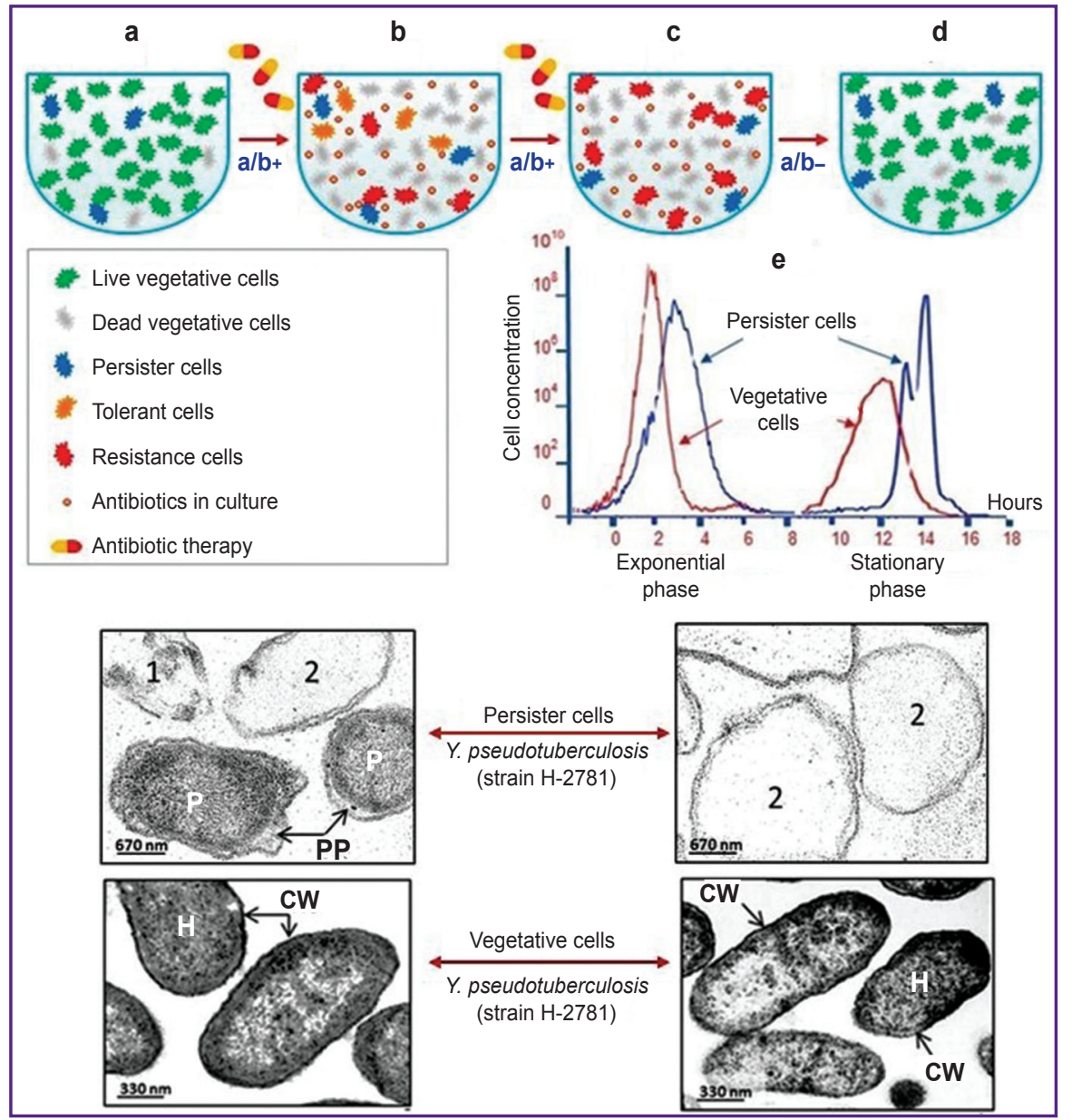

Figure 2. Persister cells in a population of vegetative cells under antibiotic therapy:

(a) before treatment; (b) and (c) during antibiotic therapy; (d) restored cell population after the end of treatment; (e) the growth rate of vegetative cells and persisters in the exponential and stationary phases of proliferation. Photo - periodic culture (Y. pseudotuberculosis, strain $\mathrm{H}-2781$ ): 1 - transient form; 2 - cells with an empty cytosol; $P$ - persister cell; $P P$ - periplasmic space; $C W$ - cell wall. Transmission electron microscopy by JEM-100 S (JEOL, Japan). Authors' depiction; photo by Somova

preservation of cell viability and resistance to antibiotics, and the formation of persister cells (by modulating the activity of RNA polymerase, lysine decarboxylase, primase, and others) [91, 92, 94]. In turn, the synthesis and modulation of the intracellular (p)ppGpp nucleotide concentration are controlled by the cytoplasmic superfamily of RelA/SpotT enzymes, which are a separate class of (p)ppGpp synthases that are sensitive to amino acid deficiency $[92,95]$.

Over the decades of study, the understanding of the physiological role of ( $p$ )ppGpp nucleotides has evolved from the concept of "strict response" to the most important signaling function - regulation of bacterial growth and metabolic activity, as well as linkage to TAS genetic loci $[90,92,96]$. These loci are crucial for the mechanism of bacterial persistence. The next section provides more details on the structure and function of TAS.

Persister cells and toxin-antitoxin systems. The loci encoding for toxins-antitoxins pairs were first found by Ogura and Hiraga in the mini-F-plasmid and then described as important genetic elements maintaining the plasmid stability in daughter cells [97].

The discovery of TAS in 2004 resulted from studies on cell persistence; that was followed by a powerful increase in the research into these unique protein structures. It turns out that TAS contribute, to a large extent, into the resistance of persister cells to antibiotics $[16,19]$.

These genetic modules usually contain two genes encoding for the stable toxin and the unstable antitoxin; the latter is sensitive to degradation by cellular proteases. It has been found that TAS are actively involved in the formation of biofilms, as well as in the development of multidrug resistance and virulence in pathogenic bacteria $[17,20,98]$.

Under normal conditions, the toxin and antitoxin are bound to each other, thus forming a non-toxic complex $[18,99,100,101]$. Under stress caused by adverse environmental conditions, antitoxins are degraded either by ATP-dependent Lon protease [100] or by the serine bacterial protease systems CIpXP $[19,100,102]$ and ClpAP [99, 100, 103]. The released toxin causes a sharp decrease in translation, replication and cell growth, thus dramatically increasing the resistance to antibiotics. Studies have shown that TAS modules are widely distributed among bacterial chromosomes. There are six types of TAC modules (I-VI) that differ in the genetic organization, the nature of the antitoxin and the mechanism of its interaction with the toxin $[98,103]$.

In all types of TAS, toxins are proteins, whereas antitoxins can be RNA molecules (types I and III) or peptides (types II, IV-VI). The most studied are 
modules of types I and II. TAS type I toxins are small hydrophobic peptides that inhibit the electrical membrane potential and stop the bacterial cell growth. Antitoxin inhibits the activity of the toxin protein by binding mRNA [17, 19, 98, 104].

Type II TAS modules are the most common. Toxins of this type suppress cell replication by inhibiting the activity of DNA gyrase (DNA topoisomerase II). Yet most of them act as inhibitors of translation using their own endoribonuclease (catalyzing the degradation of RNA) or inactivating glutamyl-tRNA-synthase (GItX) [19, 98, 105]. Antitoxins of this type - proteins - block the toxin by direct binding [105].

The leading role of TAS type II in the formation of the persistence phenomenon is evidenced by the fact that the first discovered gene of bacterial resistance hipA [18] encodes for toxin of the same name in the hipBA gene locus of TAS type II [106]. In addition, in persister cells of model wild E. coli strains, overexpression of some type II toxins was detected in the relE genes (the relBE genetic locus), mazF (mazEF locus), dinJ (dinJ-yafQ locus), and $m q s R$ (mqsQR locus) [19, 20,107].

In the same models, a similar overexpression of TAS type I toxins - tisB (tisB-istR locus) and hokB (hokBsok $B$ locus) was detected under antibiotic therapy; this overexpression is associated with high levels of (p)ppGpp, which causes depolarization of the cell membrane, a sharp decrease in metabolic activity, and the formation of stable persister cells $[19,92,105,108]$.

In a microbial cell, toxins suppress key cellular processes, such as DNA replication and protein synthesis. This inhibition leads to an instant growth arrest, a sharp decrease in the metabolic activity, and the formation of partial or complete resistance to antibiotics $[16,20,102]$. For example, release of the RelE toxin from the RelE-RelB module leads to a 10,000 -fold increase in resistance to vancomycin [101], that of the YafQ toxin - to a 2400-fold increase in resistance to cefazolin and tobramycin [103], and that the TisB toxin confers resistance to ampicillin, ciprofloxacin, and streptomycin [10, 98].

Persister cells as an object of medical technologies. The reduced efficacy of current antimicrobial agents requires studying the nature of multidrug-resistance in microorganisms. We also need to intensify the development of new antimicrobial agents targeting fundamentally different intracellular targets [64, $108,109]$. Among other areas, studying the role of $(p)$ ppGpp and TAS in the development of resistant cellular forms is especially important $[91,95,110]$.

Selective inhibition of the (p)ppGpp synthesis is crucial for the formation of cellular persistence. In recent studies, Beljantseva et al. [93] and Syal et al. [94] showed the possibility of blocking the (p)ppGpp production by suppressing the RelA/SpoT activity with non-biogenic inhibitors of the (p)ppGpp synthesis. Thus, using the synthetic compound Relacin (first proposed for this purpose in 2012 [111]), it was possible to modulate the metabolic activity and drug resistance in mycobacteria [94].

In the recent decade, the possibility of using TAS as cellular targets for antimicrobials has been studied. A number of innovative strategies have been proposed $[17,20,107]$. One of them suggested the destruction of the TAS complex with the subsequent activation of the released toxin or the inhibition of the TAS formation. This can be achieved by adding biomolecules to bind the antitoxin [16, 17, 92, 110]. Another strategy is about the activation of cellular proteolytic enzymes (hydrolases) that cause the labile protein-antitoxin TAS complex to degrade by cleaving the peptide bond, resulting in the release of the toxin [16, 92]. An additional idea proposes a direct activation of the released toxin following the inhibition of transcription in the promoter of the TAS operon [17, 110]. The short-lived antitoxin left without replenishment degrades, and the free toxin attacks the respective targets in the bacterial cell. These three strategies imply using the TAS type II modules, which are commonly found in bacteria $[98,102,104]$.

Finally, pharmacological inhibition of antitoxin translation is possible [95, 103, 105]. Antisense RNA complementary binds to the antitoxin mRNA, and thus inhibits the translation of antitoxin and the release of toxin. This approach can be applied to all types of TAS modules.

In summary, the above strategies are based on the release of free toxin, which then attacks the intracellular targets in a bacterial cell and ultimately causes its death.

It would seem that compounds containing this toxin are real candidates for the role of therapeutic agents active against multi-drug resistance bacteria. However, clinical trials of several biomolecular agents have revealed serious obstacles in the way to their practical use: the lack of oral dosage formulations and high costs of the drugs [95, 111]. In addition, questions remain about the targeted delivery of the toxins to the locations of pathogenic bacteria in the human body without having adverse effects on eukaryotic cells and normal human microbiota [92, 98, 111].

Another, more complex strategy proposes to treat the pathogens with bacteriophages that contain recombinant nucleic acids, including the gene encoding for the biosynthesis of toxin. There, RNA or DNA is integrated into the lysogenic cycle of the genome in a pathogenic bacterium; the recombinant toxins are released and kill the bacterial cell [106]. To date, recombinant nucleic acids with different genes encoding for the synthesis of toxins from many well-known TAS modules have been obtained. However, the use of bacteriophages is still limited due to their high specificity for certain microorganisms [106, 110, 112].

There is a concern that the artificial activation of toxins may stimulate the formation of persistent or dormant cells and thus lead to chronic infection. In this regard, another strategy under consideration proposes to "wake 
up" a persistent bacterial cell and make it sensitive to antibiotics [20, 109, 113].

Considering the absence of TAS genetic modules in mammals, including humans, new technologies can be aimed at creating effective and highly specific biochemical modulators of the toxin-antitoxin interactions. One possible reason for the previous failures of these antimicrobial strategies is the high presence of TAS in the genome of normal microbiota that exists in symbiosis with the human body. This necessitates the development of drugs aimed at several microbial systems, including probiotic cells.

Another problem with this therapeutic strategy is that it is not enough to simply activate toxins; their activity must be later blocked by other drugs [108, 112]. Nevertheless, the extensive basic research on TAS in pathogenic bacteria is expected to provide valuable information for the creation of new alternative antibacterials.

Thus, most recent developments are aimed primarily at overcoming the antibiotic resistance of dormant forms of bacteria. The problem of drug resistance is also associated with another form of cellular persistence viable but nonculturable cells (VBNC).

Viable but unculturable cells. For accurate determination of bacteria counts and viability, the culture method - one of the basic research tools in microbiology - is used [1, 2]. In 1982, Xu et al. [31] found that under unfavorable conditions, Escherichia coli and Vibrio cholerae can enter a special physiological state; the authors named that "viable but nonculturable cells".

Further studies [113-116] have shown that VBNC, when exposed to adverse environmental factors (starvation, hypoxia, hydrothermal changes, increased salinity, antimicrobial agents, disinfectants), are characterized by a transient loss of the ability to form colonies on solid nutrient media. At the same time, many species of bacteria retain their proliferative potential and can reverse from the VBNC state to the culturable state after the stress factor is removed and the cells have been preactivated in a liquid medium [114, 115-118].

Recent studies [119] confirm the hypothesis proposed at the end of the $X X$ century that the VBNC state represents another adaptation strategy of survival of non-sporogenous bacteria in suboptimal environmental conditions [120, 121]. In the literature, these resistant cellular forms are mentioned under various alternative names: nonculturable cells [114, 116, 122], conditionally viable environmental cells (CVEC) [1, 120], active but nonculturable cells (ABNC) [1], and dormant cells [1, 2, 123].

Unlike vegetative forms of bacteria, VBNC cells lose their ability to grow and form colonies on nutrient media, while maintaining the signs of viability: intact cell membrane, intact genome, continued gene transcription and $\mathrm{mRNA}$ production, preserved plasmids, metabolic activity, nutrient intake, and respiration driven by energy requirements [119, 123, 124].
Despite the fact that bacteria in the VBNC state possess a number of characteristics identical with their cultured precursors, their physiological and molecular properties differ significantly. This is due to the changes in cell morphology: the size (it is decreased and the surface/volume ratio changed) and shape (in the majority of VBNC bacteria, coccoid variants prevail) $[118,122]$. In addition, VBNC contain a different amount of proteins, fatty acids, and peptidoglycans in the CW. Specifically, these cells have a different expression of outer membrane proteins, a significant increase in unsaturated fatty acids, and a different proportion of hexadecanoic, hexadecenoic and octadecanoic acids. These changes are aimed at increasing the ability of bacteria in this nonculturable state to resist external mechanical damage [114, 121, 123].

Bacterial VBNC have a lower level of metabolism and reduced activity of macromolecular synthesis compared with their culturable precursors, especially those in the exponential growth phase [115, 117]. In VBNC, the energy is mainly provided by the metabolism of branched-chain amino acids [123, 124]. Compared to culturable cells, VBNC have greater physical and chemical resistance (to high temperature, ultrasound, $\mathrm{pH}$, salinity, ethanol, chlorine-containing drugs, heavy metals, oxidative and osmotic stress), and also increased resistance to antibiotics [115, 116, 118, 125].

In addition, VBNC have a slower rate of adhesion (and, accordingly, biofilm formation) and reduced expression of virulence genes compared with their culturable analogues, while maintaining the potential ability to cause severe infections after rapid reversion to the vegetative state $[117,119,121,126]$. Therefore, negative results of routine bacteriological tests may conceal a possible threat of subsequent infection [119, 127].

For a long time, the mechanism of VBNC formation in a population of bacterial cells was explained in most reports $[116,120,128]$ by the stochastic variability of their phenotypes determined by genes (first of all, by the expression of the rpoS gene encoding for the RpoS protein, one of the main factors of stress resistance associated with the signaling ( $p$ )ppGpp molecule). Other theories implicated the environment and the "random noise" inevitably present at all levels of biological organization starting from the molecular level.

Attitudes toward nonculturable variants of bacteria changed with the accumulation of experimental results. Some authors considered VBNC as degenerative forms that precede the death of bacteria and do not cause infections, even though they retain some virulent potential [114, 123]. Later, the clinical significance of nonculturable forms was confirmed by numerous studies [113, 117, 127-129]. Over the past decades, nonculturable cells were found in over 100 species of bacteria from 40 genera; of those, more than 60 species were pathogenic or opportunistic for humans and animals [119, 121, 124, 130]. 
Among the bacteria confirmed as having VBNC forms, causative agents of sapronoses - plague, pseudotuberculosis, intestinal yersiniosis, listeriosis, cholera, tularemia, and legionellosis - were found. It was documented that VBNC made it possible to preserve these pathogenic bacteria in the environment during the inter-epidemic period (saprophytic phase) thus maintaining the center of a subsequent epidemic recurrence. While in the nonculturable state, causative agents cannot initiate an infectious process. However, after the ingestion into a human or animal body (during the parasitic phase), their virulence is restored, which leads to sporadic or epidemic infections, including nosocomial and foodborne diseases (Figure 3) [114, $121,125]$.

To date, a lot of convincing evidence indicates that VBNC, like persister cells represent survival strategies for bacteria under adverse growth conditions. Numerous data have been accumulated on the biochemical, morphological, and functional similarity between the phenomena of persisting cells and VBNC bacteria (for more details, see [119, 122, 125]).

Based on the similarity of the occurrence, morphological features and genetic mechanisms of these stable forms, some authors [114, 116, 127] put an equal sign between them, considering the differences between the persisters and VBNC artificial and not having a fundamental significance. Based on a common genetic mechanism, Ayrapetyan et al. [131] combined these physiological states of bacteria into a "rest continuum" model, whereas Kim et al. [132] showed that VBNC and persister cells are identical in bacteria under stress.

However, most studies indicate a difference that has been repeatedly confirmed experimentally. It is about the inability of VBNC to quickly restore their growth after the cessation of the stress conditions; the full restoration does not occur until after $24 \mathrm{~h}$. In contrast, upon the completion of antibiotic therapy, persisting cells restore the growth on solid media much faster. This is especially true for cells that were in a state of exponential growth before the onset of persistence; in these cells, the reversion begins within $1-2 \mathrm{~h}$ after antibiotic therapy has been stopped (see Figure 2 (e)) $[88,132,133]$.

In addition, in contrast to a subpopulation of persister cells with their phenotypic resistance to antibiotics, bacteria in the VBNC state show an additional resistance

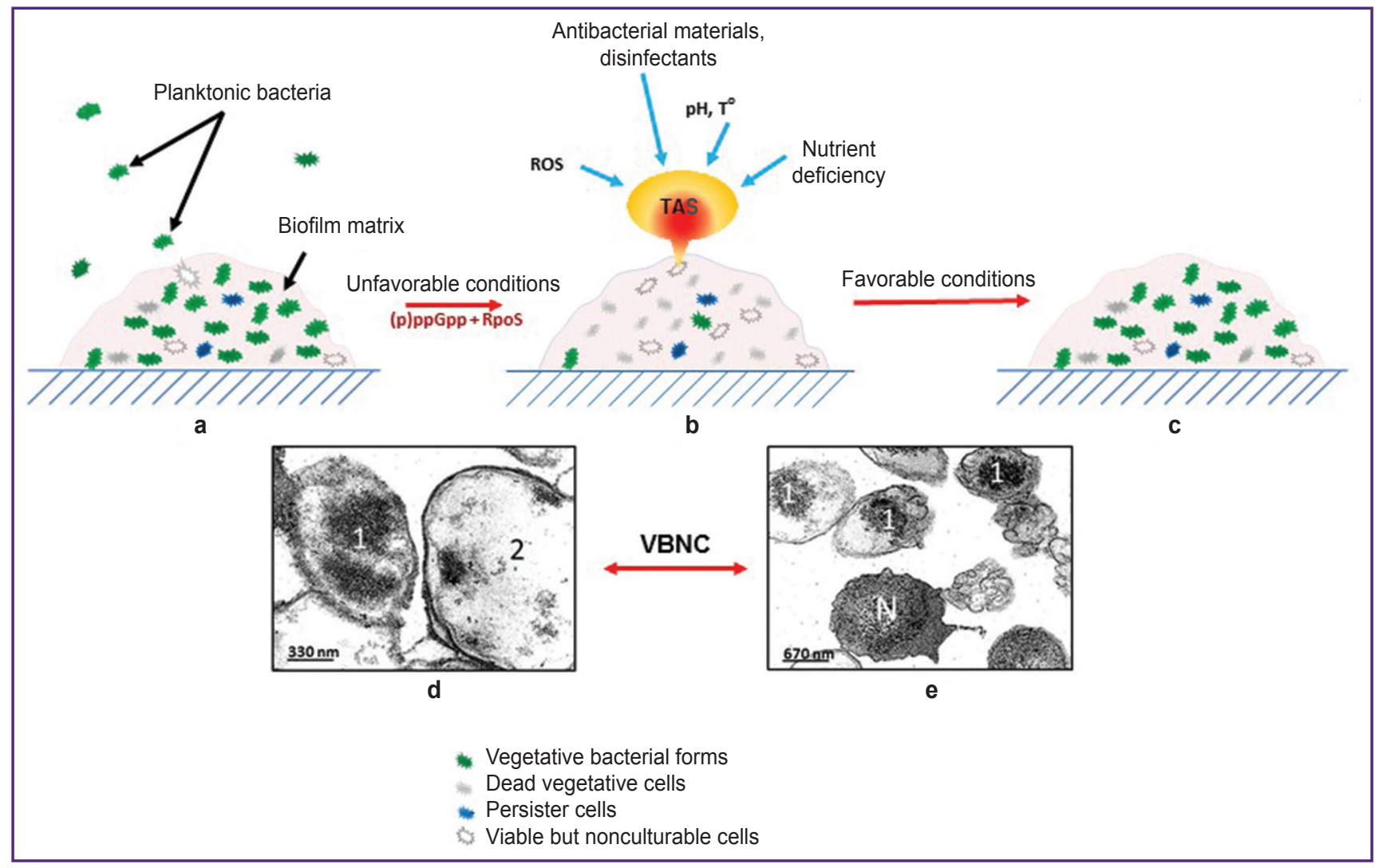

Figure 3. Formation and proliferation of viable but nonculturable (VBNC) forms of bacteria:

(a) the formation of biofilms under normal conditions; (b) adverse conditions, formation of VBNC; (c) recovery of the population at the onset of favorable conditions. TAS — toxin-antitoxin system; ROS — reactive oxygen species. Photo: (d), (e) periodic culture (Y. pseudotuberculosis, strain $\mathrm{H}-2781$ ), nutrient broth, $37^{\circ} \mathrm{C} ; 1-$ VBNC transient form; 2 - cells with an empty cytosol; $N-$ a normal cell. Transmission electron microscopy by JEM-100 S (JEOL, Japan). Authors' depiction; photo by Somova 
to a variety of chemical and physical factors, including a wide range of antimicrobial agents and disinfectants, which makes them highly significant as agents of intrahospital infections. With the morphological similarity between these states, the time of the post-stress growth onset is the main pathognomonic sign, which allows one to distinguish between VBNC and persister cells [89, 91, 132, 134].

At the same time, some authors believe [135] that a small number of persister cells is a prerequisite for the accumulation of VBNC cells and that these persisting cells represent a transitional stage before being fully transformed into VBNC.

Viable but nonculturable cells as an object of medical technologies. The recent data on the formation of nonculturable bacteria have increased scientific and practical interest in VBNC. Specifically, more research into the phenomenon of bacterial persistence is under way.

The current technologies aim at the improvement of microbiological detection and morphological identification of VBNC forms in bacteria, as well as the conditions and methods for their re-cultivation ("reanimation") and the tools for inhibiting the formation of these dormant forms [128-130, 131-133, 135-138].

As mentioned above, pathogenic bacteria in the VBNC state do not grow in regular diagnostic media. In the form of VBNC, most microbial species cannot be cultivated using traditional methods, and therefore remain unidentified in clinical samples. Identification of these forms is based on comparing the number of viable cells with the number of cultured cells in the sample. As a rule, this is done by the usual cell counting method. If the number of cultured cells decreases and the number of viable bacteria remains high, it is concluded that the sample contains VBNC forms $[121,124,126,134]$.

The second important step for identifying VBNC bacteria is the measurement of their viability. Radioisotope methods of cell analysis based on the incorporation of radioactive precursors into bacterial metabolism (the D. Kennel method), evaluation of the proteolytic activity and acid formation [1, 2], cytochemical assays with tetrazolium salts for assessing the generation of ATP and electron transport systems remain relevant until now $[1,121,124]$.

However, in the XXI century, the identification of dormant cell forms is preferably based on intravital imaging and supravital staining that have been designed for microbiological studies. The Life Technologies and LIVE/DEAD BacLight Bacterial Viability Kit systems (ThermoFisher Scientific, USA) containing fluorescent markers have become common tools for studying the metabolism and viability of bacteria; these methods are able to probe the integrity of the cell membrane [130, $136,137]$. The differential staining method is based on the supravital detection of vegetative and dormant cell forms, as well as dead bacteria, and can be used for direct fluorescence microscopy, fluorescent microplate readings and flow cytometry [132, 138].

In case the microbiological analysis produces negative results, the presence of VBNC can be tested using molecular genetic test systems [136, 137] or matrix-activated laser desorption-ionization time-of-flight mass spectrometry (MALDI-ToF/MS) [138, 139].

By applying these methods, Ayrapetyan et al. $[129,131,133]$ showed that in $14-27 \%$ of infections, pathogens in the form of VBNC remained undetected by traditional microbiological tests, and their presence was revealed only by PCR. A quantitative increase in the subpopulation of nonculturable forms in biofilms was reported; that also emphasizes the role of innovative methods in the detection of human bacterial infections (see Figure 3) [94, 95, 104, 140, 141].

Understanding the VBNC induction and reversion is crucial for controlling the formation and resuscitation of nonculturable bacterial cells. Liu et al. [142] found that chlorinated tap water induced the formation of VBNC in $90 \%$ of Escherichia coli O157:H7 within $15 \mathrm{~min}$. For comparison, in river water the formation of VBNC occurred within 14 weeks and only in $14 \%$ of E. coli. Similar induction efficiencies were found under starvation combined with low osmotic pressure, whereas starvation alone did not induce the formation of VBNC for at least 1.5 years of observation. In 10-month-old VBNC induced by chlorinated water, viability and restoration by $\mathrm{Al}-2$ autoinducers from $E$. coli $\mathrm{O} 157: \mathrm{H} 7$ was found in a serum-supplemented medium. Further studies have shown that methionine, glutamine, threonine, serine, and asparagine, as well as pyruvate (glutamate) [142], Tween 20 or catalase [143] contribute to prompt reversion of $E$. coli.

A breakthrough in studying VBNC-bacteria was the discovery in a culture medium of Micrococcus luteus of a factor that helped restore viability of dormant microorganisms (resuscitation promoting factor, Rpf). This factor represents a family of thermolabile proteins with a molecular mass of 16-19 kDa and a high muralytic activity; in picomolar concentrations, Rpf can induce the division and growth of VBNC by remodeling their cell walls (peptidoglycan hydrolysis) [144-146].

In the medicine of today, the relevance of using Rpf proteins is associated with the transition of a latent chronic form of tuberculosis infection to active tuberculosis. Therefore, inhibiting the factor essential for the Mycobacterium tuberculosis resuscitation (for example, by specific antibodies or nitrophenylthiocyanate compounds) is an attractive strategy to combat the reactivation of latent tuberculosis $[147,148]$.

\section{Conclusion}

Several decades have passed since the discovery of bacterial persistence in non-sporogenous bacteria. During that time, significant progress has been made 
toward the understanding of the nature, biological role and mechanisms of formation of dormant cell forms.

In nature, many microorganisms live in variable conditions and experience the impact of suboptimal environmental factors. Phenotypic plasticity of bacteria associated with the resting state is characterized by low metabolic and reproductive activity. It is a common and sometimes prevailing response of bacteria to environmental stresses. At the same time, the transient formation of dormant forms in non-sporogenous bacteria is an important tool for maintaining their viability and virulence, resistance to antimicrobial drugs and the ability to cause chronic infections in the host organism.

The above mentioned area of research is not only of fundamental importance but also opens up broad prospects for the development of novel antimicrobial technologies. The high occurrence rate of multidrug resistance in pathogenic bacteria is a major incentive of such kind of research.

The development of innovative technologies based on the accumulated knowledge will help identify and classify the dormant forms of bacteria and create effective therapeutic strategies against latent chronic infections. In addition, phenotypic plasticity of bacteria allows scientists to study the intercellular interaction between microorganisms that maintains the diversity, structure, and function of microbial communities in natural ecosystems and biocenoses.

Research funding. This study was supported by the Integrated Basic Research Program of the Far Eastern Branch of the Russian Academy of Sciences "Far East", project No.18-5-099.

Conflict of interest. The authors declare no conflict of interest.

\section{References}

1. Kaufmann S.H.E. Basiswissen Immunologie. Springer Berlin Heidelberg; 2014, https://doi.org/10.1007/978-3-64240325-5.

2. Todd I., Spickett G., Fairclough L. Lecture notes: immunologe. Wiley-Blackwell; 2015.

3. WHO. Antimicrobial resistance. 2015. URL: https:// www.who.int.

4. Errington J. L-form bacteria, cell walls and the origins of life. Open Biol 2013; 3(1): 120143-120143, https://doi. org/10.1098/rsob.120143.

5. Errington J. Cell wall-deficient, L-form bacteria in the $21^{\text {st }}$ century: a personal perspective. Biochem Soc Trans 2017; 45(2): 287-295, https://doi.org/10.1042/bst20160435.

6. Domingue G.J. Demystifying pleomorphic forms in persistence and expression of disease: are they bacteria, and is peptidoglycan the solution? Discov Med 2010; 10(52): 234-246.

7. Ferrer M., Méndez-García C., Rojo D., Barbas C., Moya A. Antibiotic use and microbiome function. Biochem Pharmacol 2017; 134: 114-126, https://doi.org/10.1016/j. bcp.2016.09.007.

8. Domingue G.J., Woody H.B. Bacterial persistence and expression of disease. Clin Microbiol Rev 1997; 10(2): 320344, https://doi.org/10.1128/cmr.10.2.320.

9. Van Teeseling M.C.F., de Pedro M.A., Cava F. Determinants of bacterial morphology: from fundamentals to possibilities for antimicrobial targeting. Front Microbiol 2017; 8, https://doi.org/10.3389/fmicb.2017.01264.

10. Kysela D.T., Randich A.M., Caccamo P.D., Brun Y.V. Diversity takes shape: understanding the mechanistic and adaptive basis of bacterial morphology. PLoS Biol 2016; 14(10): e1002565, https://doi.org/10.1371/journal.pbio.1002565.

11. Dörr T., Davis B.M., Waldor M.K. Endopeptidasemediated beta lactam tolerance. PLoS Pathog 2015; 11(4): e1004850, https://doi.org/10.1371/journal.ppat.1004850.

12. Dziarski R., Gupta D. How innate immunity proteins kill bacteria and why they are not prone to resistance. Curr Genet 2017; 64(1): 125-129, https://doi.org/10.1007/s00294-0170737-0.

13. Sassine J., Xu M., Sidiq K.R., Emmins R., Errington J., Daniel R.A. Functional redundancy of division specific penicillin-binding proteins in Bacillus subtilis. Mol Microbiol 2017; 106(2): 304-318, https://doi.org/10.1111/mmi.13765.

14. Errington J., Mickiewicz K., Kawai Y., Wu L.J. L-form bacteria, chronic diseases and the origins of life. Philos Trans R Soc Lond B Biol Sci 2016; 371(1707): 20150494, https://doi. org/10.1098/rstb.2015.0494.

15. Somova L.M., Buzoleva L.S., Plekhova N.G. Ul'trastruktura patogennykh bakteriy $v$ raznykh ekologicheskikh usloviyakh [Ultrastructure of pathogenic bacteria in different environmental conditions]. Vladivostok: Meditsina DV; 2009; $200 \mathrm{p}$

16. Kędzierska B., Hayes F. Emerging roles of toxinantitoxin modules in bacterial pathogenesis. Molecules 2016; 21(6): 790, https://doi.org/10.3390/molecules21060790.

17. Lee K.-Y., Lee B.-J. Structure, biology, and therapeutic application of toxin-antitoxin systems in pathogenic bacteria. Toxins 2016; 8(10): 305, https://doi.org/10.3390/ toxins8100305.

18. Hayes F. Toxins-antitoxins: plasmid maintenance, programmed cell death, and cell cycle arrest. Science 2003; 301(5639): 1496-1499, https://doi.org/10.1126/ science.1088157.

19. Brown B.L., Grigoriu S., Kim Y., Arruda J.M., Davenport A., Wood T.K., Peti W., Page R. Three dimensional structure of the MqsR:MqsA complex: a novel TA pair comprised of a toxin homologous to RelE and an antitoxin with unique properties. PLoS Pathog 2009; 5(12): e1000706, https://doi.org/10.1371/journal.ppat.1000706.

20. Chan W.T., Balsa D., Espinosa M. One cannot rule them all: are bacterial toxins-antitoxins druggable? FEMS Microbiol Rev 2015; 39(4): 522-540, https://doi.org/10.1093/ femsre/fuv002.

21. Kawai Y., Mercier R., Errington J. Bacterial cell morphogenesis does not require a preexisting template structure. Curr Biol 2014; 24(8): 863-867, https://doi. org/10.1016/j.cub.2014.02.053.

22. Harms A., Maisonneuve E., Gerdes K. Mechanisms of bacterial persistence during stress and antibiotic exposure. Science 2016; 354(6318): aaf4268, https://doi.org/10.1126/ science.aaf4268.

23. Randich A.M., Brun Y.V. Molecular mechanisms for the evolution of bacterial morphologies and growth modes. Front Microbiol 2015; 6: 580, https://doi.org/10.3389/ fmicb.2015.00580. 
24. Ragland S.A., Criss A.K. From bacterial killing to immune modulation: recent insights into the functions of lysozyme. PLoS Pathog 2017; 13(9): e1006512, https://doi. org/10.1371/journal.ppat.1006512.

25. Aguilar B., Ghaffarizadeh A., Johnson C.D., Podgorski G.J., Shmulevich I., Flann N.S. Cell death as a trigger for morphogenesis. PLoS One 2018; 13(3):e0191089, https://doi.org/10.1371/journal.pone.0191089.

26. Timakov V.D., Kagan G.Ya. L-forma bakteriy $i$ semeystvo Mycoplasmataceae $v$ patologii [L-form bacteria and the Mycoplasmataceae family in pathology]. Moscow: Meditsina; 1973; 392 p.

27. Kawai Y., Mercier R., Wu L.J., Domínguez-Cuevas P., Oshima T., Errington J. Cell growth of wall-free L-form bacteria is limited by oxidative damage. Curr Biol 2015; 25(12): 16131618, https://doi.org/10.1016/j.cub.2015.04.031.

28. Kawai Y., Mickiewicz K., Errington J. Lysozyme counteracts $\beta$-lactam antibiotics by promoting the emergence of L-form bacteria. Cell 2018; 172(5): 1038-1049.e10, https:// doi.org/10.1016/j.cell.2018.01.021.

29. Fisher R.A., Gollan B., Helaine S. Persistent bacterial infections and persister cells. Nat Rev Microbiol 2017; 15(8): 453-464, https://doi.org/10.1038/nrmicro.2017.42.

30. Klieneberger E. The natural occurrence of pleuropneumonia-like organism in apparent symbiosis with Streptobacillus moniliformis and other bacteria. I Pathol Bacteriol 1935; 40(1): 93-105, https://doi.org/10.1002/ path. 1700400108.

31. Xu H.-S., Roberts N., Singleton F.L., Attwell R.W., Grimes D.J., Colwell R.R. Survival and viability of nonculturable Escherichia coli and Vibrio cholerae in the estuarine and marine environment. Microb Ecol 1982; 8(4): 313-323, https:// doi.org/10.1007/bf02010671.

32. Hobby G.L., Meyer K., Chaffee E. Observations on the mechanism of action of penicillin. Exp Biol Med 1942; 50(2): 281-285, https://doi.org/10.3181/00379727-50-13773.

33. Casadesús J. Bacterial L-forms require peptidoglycan synthesis for cell division. BioEssays 2007; 29(12): 1189-1191, https://doi.org/10.1002/bies.20680.

34. Allan E.J., Hoischen C., Gumpert J. Bacterial L-forms. Adv Appl Microbiol 2009; 1-39, https://doi.org/10.1016/s00652164(09)01201-5.

35. McLaughlin R.W., Vali H., Lau P.C., Palfree R.G., De Ciccio A., Sirois M., Ahmad D., Villemur R., Desrosiers M., Chan E.C. Are there naturally occurring pleomorphic bacteria in the blood of healthy humans? J Clin Microbiol 2002; 40(12): 4771-4775, https://doi.org/10.1128/jcm.40.12.47714775.2002

36. Briers Y., Walde P., Schuppler M., Loessner M.J. How did bacterial ancestors reproduce? Lessons from L-form cells and giant lipid vesicles: multiplication similarities between lipid vesicles and L-form bacteria. BioEssays 2012; 34(12): 10781084, https://doi.org/10.1002/bies.201200080.

37. Domínguez-Cuevas P., Mercier R., Leaver M., Kawai Y., Errington J. The rod to L-form transition of Bacillus subtilis is limited by a requirement for the protoplast to escape from the cell wall sacculus. Mol Microbiol 2011; 83(1): 52-66, https://doi. org/10.1111/j.1365-2958.2011.07920.x.

38. Mercier R., Kawai Y., Errington J. General principles for the formation and proliferation of a wall-free (L-form) state in bacteria. eLife 2014; 3, https://doi.org/10.7554/elife. 04629 .

39. Markova N., Slavchev G., Michailova L., Jourdanova M.
Survival of Escherichia coli under lethal heat stress by L-form conversion. Int J Biol Sci 2010; 6(4): 303-315, https://doi. org/10.7150/ijbs.6.303.

40. Markova N., Slavchev G., Michailova L. Presence of mycobacterial L-forms in human blood: challenge of BCG vaccination. Hum Vaccin Immunother 2015; 11(5): 1192-1200, https://doi.org/10.1080/21645515.2015.1016682.

41. Markova N., Slavchev G., Djerov L., Nikolov A., Dimova T. Mycobacterial L-forms are found in cord blood: a potential vertical transmission of BCG from vaccinated mothers. Hum Vaccin Immunother 2016; 12(10): 2565-2571, https://doi.org/10.1080/21645515.2016.1193658.

42. Markova N.D. L-form bacteria cohabitants in human blood: significance for health and diseases. Discov Med 2017; 23(128): 305-313.

43. Slavchev G., Michailova L., Markova N. L-form transformation phenomenon in Mycobacterium tuberculosis associated with drug tolerance to ethambutol. Int $J$ Mycobacteriol 2016; 5(4): 454-459, https://doi.org/10.1016/j. ijmyco.2016.06.011.

44. Lovering A.L., Safadi S.S., Strynadka N.C.J. Structural perspective of peptidoglycan biosynthesis and assembly. Annu Rev Biochem 2012; 81(1): 451-478, https://doi.org/10.1146/ annurev-biochem-061809-112742.

45. Emami K., Guyet A., Kawai Y., Devi J., Wu L.J., Allenby N., Daniel R.A., Errington J. RodA as the missing glycosyltransferase in Bacillus subtilis and antibiotic discovery for the peptidoglycan polymerase pathway. Nat Microbiol 2017; 2(3), https://doi.org/10.1038/nmicrobiol.2016.253.

46. Mercier R., Domínguez-Cuevas P., Errington J. Crucial role for membrane fluidity in proliferation of primitive cells. Cell Rep 2012; 1(5): 417-423, https://doi.org/10.1016/j. celrep.2012.03.008.

47. Kashyap D.R., Rompca A., Gaballa A., Helmann J.D., Chan J., Chang C.J., Hozo I., Gupta D., Dziarski R. Peptidoglycan recognition proteins kill bacteria by inducing oxidative, thiol, and metal stress. PLoS Pathog 2014; 10(7): e1004280, https://doi.org/10.1371/journal.ppat.1004280.

48. Liu C., Xu Z., Gupta D., Dziarski R. Peptidoglycan recognition proteins. J Biol Chem 2001; 276(37): 3468634694, https://doi.org/10.1074/jbc.m105566200.

49. Budin I., Szostak J.W. Expanding roles for diverse physical phenomena during the origin of life. Annu Rev Biophys 2010; 39(1): 245-263, https://doi.org/10.1146/annurev. biophys.050708.133753.

50. Kawai Y., Mickiewicz K., Errington J. Lysozyme counteracts $\beta$-lactam antibiotics by promoting the emergence of L-form bacteria. Cell 2018; 172(5): 1038-1049, https://doi. org/10.1016/j.cell.2018.01.021.

51. Justice S.S., Hunstad D.A., Cegelski L., Hultgren S.J. Morphological plasticity as a bacterial survival strategy. Nat Rev Microbiol 2008; 6(2): 162-168, https://doi.org/10.1038/ nrmicro1820.

52. Asnani P.J., Gill K. Biological properties of L-forms and their parent bacteria. Acta Microbiol Acad Sci Hung 1980; 27(2): 131-134.

53. Ferguson C.M.J., Booth N.A., Allan E.J. An ELISA for the detection of Bacillus subtilis L-form bacteria confirms their symbiosis in strawberry. Lett Appl Microbiol 2000; 31(5): 390394, https://doi.org/10.1046/j.1472-765x.2000.00834.x.

54. Tedeschi G.G., Amici D., Sprovieri G., Vecchi A. Staphylococcus epidermidis in the circulating blood of normal and thrombocytopenic human subjects: immunological data. 
Experientia 1976; 32(12): 1600-1602, https://doi.org/10.1007/ bf01924475.

55. Seel W., Flegler A., Zunabovic-Pichler M., Lipski A. Increased isoprenoid quinone concentration modulates membrane fluidity in Listeria monocytogenes at low growth temperatures. J Bacteriol 2018; 200(13): e00148-18, https:// doi.org/10.1128/jb.00148-18.

56. Chintalapati S., Kiran M.D., Shivaji S. Role of membrane lipid fatty acids in cold adaptation. Cell Mol Biol 2004; 50(5): 631-642.

57. Andryukov B.G., Somova L.M., Timchenko N.F. Fatty acid as an object of research of temperature adaptation strategies psychrophiles. Zdorov'e. Meditsinskaya ekologiya. Nauka 2015; 3(61): 43-49.

58. Studer P., Staubli T., Wieser N., Wolf P., Schuppler M., Loessner M.J. Proliferation of Listeria monocytogenes L-form cells by formation of internal and external vesicles. Nat Commun 2016; 7(1), https://doi.org/10.1038/ncomms13631.

59. Bigger J. Treatment of staphylococcal infections with penicillin by intermittent sterilisation. Lancet 1944; 244(6320): 497-500, https://doi.org/10.1016/s0140-6736(00)74210-3.

60. Balaban N.Q. Bacterial persistence as a phenotypic switch. Science 2004; 305(5690): 1622-1625, https://doi. org/10.1126/science.1099390.

61. Han J., Shi W., Xu X., Wang S., Zhang S., He L., Sun X., Zhang Y. Conditions and mutations affecting Staphylococcus aureus L-form formation. Microbiology 2015; 161(1): 57-66, https://doi.org/10.1099/mic.0.082354-0.

62. Onwuamaegbu M., Belcher R., Soare C. Cell walldeficient bacteria as a cause of infections: a review of the clinical significance. J Int Med Res 2005; 33(1): 1-20, https:// doi.org/10.1177/147323000503300101.

63. Beaman B.L., Scates S.M. Role of L-forms of Nocardia caviae in the development of chronic mycetomas in normal and immunodeficient murine models. Infect Immun 1981; 33(3): 893-907.

64. Gupta R.S. Origin of diderm (gram-negative) bacteria: antibiotic selection pressure rather than endosymbiosis likely led to the evolution of bacterial cells with two membranes. Antonie Van Leeuwenhoek 2011; 100(2): 171-182, https://doi. org/10.1007/s10482-011-9616-8.

65. Bertaux F., Marguerat S., Shahrezaei V. Division rate, cell size and proteome allocation: impact on gene expression noise and implications for the dynamics of genetic circuits. $R$ Soc Open Sci 2018; 5(3): 172234, https://doi.org/10.1098/ rsos. 172234

66. Glover W.A., Yang Y., Zhang Y. Insights into the molecular basis of L-form formation and survival in Escherichia coli. PLoS One 2009; 4(10): e7316, https://doi.org/10.1371/ journal.pone.0007316.

67. Dhar N., McKinney J.D. Microbial phenotypic heterogeneity and antibiotic tolerance. Curr Opin Microbiol 2007; 10(1): 30-38, https://doi.org/10.1016/j.mib.2006. 12.007 .

68. Allison K.R., Brynildsen M.P., Collins J.J. Metaboliteenabled eradication of bacterial persisters by aminoglycosides. Nature 2011; 473(7346): 216-220, https://doi.org/10.1038/ nature 10069.

69. Barth V.C., Rodrigues B.Á., Bonatto G.D., Gallo S.W., Pagnussatti V.E., Ferreira C.A.S., de Oliveira S.D. Heterogeneous persister cells formation in Acinetobacter baumannii. PLoS One 2013; 8(12): e84361, https://doi. org/10.1371/journal.pone.0084361.
70. Day T. Interpreting phenotypic antibiotic tolerance and persister cells as evolution via epigenetic inheritance. Mol Ecol 2016; 25(8): 1869-1882, https://doi.org/10.1111/ mec.13603.

71. Amato S.M., Brynildsen M.P. Persister heterogeneity arising from a single metabolic stress. Curr Biol 2015; 25(16): 2090-2098, https://doi.org/10.1016/j.cub.2015.06.034.

72. Lewis K. Persister cells. Annu Rev Microbiol 2010; 64(1): 357-372, https://doi.org/10.1146/annurev. micro.112408.134306.

73. Levin B.R., Concepción-Acevedo J., Udekwu K.I. Persistence: a copacetic and parsimonious hypothesis for the existence of non-inherited resistance to antibiotics. Curr Opin Microbiol 2014; 21: 18-21, https://doi.org/10.1016/j. mib.2014.06.016.

74. Orman M.A., Brynildsen M.P. Inhibition of stationary phase respiration impairs persister formation in E. coli. Nat Commun 2015; 6(1), https://doi.org/10.1038/ncomms8983.

75. Patra P., Klumpp S. Population dynamics of bacterial persistence. PLoS One 2013; 8(5): e62814, https://doi. org/10.1371/journal.pone.0062814.

76. Kwan B.W., Chowdhury N., Wood T.K. Combatting bacterial infections by killing persister cells with mitomycin $\mathrm{C}$. Environ Microbiol 2015; 17(11): 4406-4414, https://doi. org/10.1111/1462-2920.12873.

77. Chowdhury N., Wood T.L., Martínez-Vázquez M., García-Contreras R., Wood T.K. DNA-crosslinker cisplatin eradicates bacterial persister cells. Biotechnol Bioeng 2016; 113(9): 1984-1992, https://doi.org/10.1002/bit.25963.

78. Lock R.L., Harry E.J. Cell-division inhibitors: new insights for future antibiotics. Nat Rev Drug Discov 2008; 7(4): 324-38, https://doi.org/10.1038/nrd2510.

79. Belov A.B., Kuzin A.A. Health care-associated sapronous infections: problematic questions of epidemiological theory. Permskiy meditsinskiy zhurnal 2017; 34(4): 94-102.

80. Nemeth J., Oesch G., Kuster S.P. Bacteriostatic versus bactericidal antibiotics for patients with serious bacterial infections: systematic review and meta-analysis. J Antimicrob Chemother 2015; 70(2): 382-395, https://doi.org/10.1093/jac/ dku379.

81. McShan A.C., De Guzman R.N. The bacterial type III secretion system as a target for developing new antibiotics. Chem Biol Drug Des 2014; 85(1): 30-42, https://doi. org/10.1111/cbdd.12422.

82. Spellberg B., Guidos R., Gilbert D., Bradley J., Boucher H.W., Scheld W.M., Bartlett J.G., Edwards J. Jr.; Infectious Diseases Society of America. The epidemic of antibiotic-resistant infections: a call to action for the medical community from the Infectious Diseases Society of America. Clin Infect Dis 2008; 46(2): 155-164, https://doi. org/10.1086/524891.

83. Kint C.I., Verstraeten N., Fauvart M., Michiels J. New-found fundamentals of bacterial persistence. Trends Microbiol 2012; 20(12): 577-585, https://doi.org/10.1016/j. tim.2012.08.009.

84. Lewis K. Platforms for antibiotic discovery. Nat Rev Drug Discov 2013; 12(5): 371-387, https://doi.org/10.1038/ nrd3975.

85. Maisonneuve E., Gerdes K. Molecular mechanisms underlying bacterial persisters. Cell 2014; 157(3): 539-548, https://doi.org/10.1016/j.cell.2014.02.050.

86. Van den Bergh B., Michiels J.E., Fauvart M., Michiels J. Should we develop screens for multi-drug antibiotic tolerance? 
Expert Rev Anti Infect Ther 2016; 14(7): 613-616, https://doi.or g/10.1080/14787210.2016.1194754.

87. Lewis K., Shan Y. Persister awakening. Mol Cell 2016; 63(1): 3-4, https://doi.org/10.1016/j.molcel.2016.06.025.

88. Amato S.M., Fazen C.H., Henry T.C., Mok W.W.K., Orman M.A., Sandvik E.L., Volzing K.G., Brynildsen M.P. The role of metabolism in bacterial persistence. Front Microbiol 2014; 5, https://doi.org/10.3389/fmicb.2014.00070.

89. Michiels J.E., Van den Bergh B., Verstraeten N., Michiels J. Molecular mechanisms and clinical implications of bacterial persistence. Drug Resist Updat 2016; 29: 76-89, https://doi.org/10.1016/j.drup.2016.10.002.

90. Wood T.K. Combatting bacterial persister cells. Biotechnol Bioeng 2015; 113(3): 476-483, https://doi. org/10.1002/bit.25721.

91. Maisonneuve E., Castro-Camargo M., Gerdes K. (p)pGpp controls bacterial persistence by stochastic induction of toxin-antitoxin activity. Cell 2013; 154(5): 1140-1150, https:// doi.org/10.1016/j.cell.2013.07.048.

92. Manav M.C., Beljantseva J., Bojer M.S., Tenson T., Ingmer H., Hauryliuk V., Brodersen D.E. Structural basis for (p)ppGpp synthesis by the Staphylococcus aureus small alarmone synthetase RelP. J Biol Chem 2018; 293(9): 32543264, https://doi.org/10.1074/jbc.ra117.001374.

93. Beljantseva J., Kudrin P., Jimmy S., Ehn M., Pohl R., Varik V., Tozawa Y., Shingler V., Tenson T., Rejman D., Hauryliuk V. Molecular mutagenesis of ppGpp: turning a RelA activator into an inhibitor. Sci Rep 2017; 7(1): 41839, https:// doi.org/10.1038/srep41839.

94. Syal K., Flentie K., Bhardwaj N., Maiti K., Jayaraman N., Stallings C.L., Chatterji D. Synthetic (p)ppGpp analogue is an inhibitor of stringent response in mycobacteria. Antimicrob Agents Chemother 2017; 61(6): e00443-17, https://doi. org/10.1128/aac.00443-17.

95. Geiger T., Goerke C., Fritz M., Schäfer T., Ohlsen K., Liebeke M., Lalk M., Wolz C. Role of the (p)ppGpp synthase $\mathrm{RSH}$, a RelA/SpoT homolog, in stringent response and virulence of Staphylococcus aureus. Infect Immun 2010; 78(5): 1873-1883, https://doi.org/10.1128/iai.01439-09.

96. Hauryliuk V., Atkinson G.C., Murakami K.S., Tenson T., Gerdes K. Recent functional insights into the role of (p)ppGpp in bacterial physiology. Nat Rev Microbiol 2015; 13(5): 298309, https://doi.org/10.1038/nrmicro3448.

97. Ogura T., Hiraga S. Mini-F plasmid genes that couple host cell division to plasmid proliferation. Proc Natl Acad Sci USA 1983; 80(15): 4784-4788, https://doi.org/10.1073/ pnas.80.15.4784.

98. Page R., Peti W. Toxin-antitoxin systems in bacterial growth arrest and persistence. Nat Chem Biol 2016; 12(4): 208-214, https://doi.org/10.1038/nchembio.2044.

99. Aizenman E., Engelberg-Kulka H., Glaser G. An Escherichia coli chromosomal "addiction module" regulated by guanosine [corrected] 3',5'-bispyrophosphate: a model for programmed bacterial cell death. Proc Natl Acad Sci U S A 1996; 93(12): 6059-6063, https://doi.org/10.1073/pnas.93.12.6059.

100. Christensen S.K., Maenhaut-Michel G., Mine N., Gottesman S., Gerdes K., Van Melderen L. Overproduction of the Lon protease triggers inhibition of translation in Escherichia coli: involvement of the yefM-yoeB toxin-antitoxin system. Mol Microbiol 2004; 51(6): 1705-1717, https://doi.org/10.1046/ j.1365-2958.2003.03941.x.

101. Van Melderen L., Saavedra De Bast M. Bacterial toxin-antitoxin systems: more than selfish entities? PLoS
Genetics 2009; 5(3): e1000437, https://doi.org/10.1371/journal. pgen.1000437.

102. Wen Y., Behiels E., Devreese B. Toxin-antitoxin systems: their role in persistence, biofilm formation, and pathogenicity. Pathog Dis 2014; 70(3): 240-249, https://doi. org/10.1111/2049-632x.12145.

103. Van Melderen L. Toxin-antitoxin systems: why so many, what for? Curr Opin Microbiol 2010; 13(6): 781-785, https://doi.org/10.1016/j.mib.2010.10.006.

104. Thakur Z., Dharra R., Saini V., Kumar A., Mehta P.K. Insights from the protein-protein interaction network analysis of Mycobacterium tuberculosis toxinantitoxin systems. Bioinformation 2017; 13(11): 380-387, https://doi. org/10.6026/97320630013380.

105. Ghafourian S., Raftari M., Sadeghifard N., Sekawi Z. Toxin-antitoxin systems: classification, biological function and application in biotechnology. Curr Issues Mol Biol 2014, 16: 9-14, https://doi.org/10.21775/cimb.016.009.

106. Hayes F., Kędzierska B. Regulating toxin-antitoxin expression: controlled detonation of intracellular molecular timebombs. Toxins 2014; 6(1): 337-358, https://doi. org/10.3390/toxins6010337.

107. Maleki A., Ghafourian S., Pakzad I., Badakhsh B., Sadeghifard N. mazE antitoxin of toxin antitoxin system and $\mathrm{fbpA}$ as reliable targets to eradication of Neisseria meningitidis. Curr Pharm Des 2018; 24(11): 1204-1210, https://doi.org/10.2 174/1381612824666171213094730.

108. Jaén-Luchoro D., Aliaga-Lozano F., Gomila R.M., Gomila M., Salvà-Serra F., Lalucat J., Bennasar-Figueras A. First insights into a type II toxin-antitoxin system from the clinical isolate Mycobacterium sp. MHSD3, similar to epsilon/ zeta systems. PLoS One 2017; 12(12): e0189459, https://doi. org/10.1371/journal.pone.0189459.

109. Wood T.K. Strategies for combating persister cell and biofilm infections. Microb Biotechnol 2017; 10(5): 1054-1056, https://doi.org/10.1111/1751-7915.12774.

110. Cui P., Xu T., Zhang W.H., Zhang Y. Molecular mechanisms of bacterial persistence and phenotypic antibiotic resistance. Yi Chuan 2016; 38(10): 859-871.

111. Wexselblatt E., Oppenheimer-Shaanan Y., Kaspy I., London N., Schueler-Furman O., Yavin E., Glaser G., Katzhendler J., Ben-Yehuda S. Relacin, a novel antibacterial agent targeting the stringent response. PLOS Pathog 2012; 8(9): e1002925, https://doi.org/10.1371/journal. ppat.1002925.

112. Kim J.S., Chowdhury N., Yamasaki R., Wood T.K. Viable but non-culturable and persistence describe the same bacterial stress state. Environ Microbiol 2018; 20(6): 20382048, https://doi.org/10.1111/1462-2920.14075.

113. Winther K.S., Roghanian M., Gerdes K. Activation of the stringent response by loading of RelA-tRNA complexes at the ribosomal A-site. Mol Cell 2018; 70(1): 95-105.e4, https:// doi.org/10.1016/j.molcel.2018.02.033.

114. Somov G.P., Buzoleva L.S. Adaptatsiya patogennykh bakteriy $k$ abioticheskim faktoram okruzhayushchey sredy [Adaptation of pathogenic bacteria to abiotic environmental factors]. Vladivostok: OAO "Poligrafkombinat"; 2004; 168 p.

115. Oliver J.D. The viable but non-culturable state in the human pathogen Vibrio vulnificus. FEMS Microbiol Lett 1995; 133(3): 203-208, https://doi.org/10.1111/j.1574-6968.1995. tb07885.x.

116. Oliver J.D. Recent findings on the viable but nonculturable state in pathogenic bacteria. FEMS Microbiol 
Rev 2010; 34(4): 415-425, https://doi.org/10.1111/j.15746976.2009.00200.x.

117. Day A.P., Oliver J.D. Changes in membrane fatty acid composition during entry of Vibrio vulnificus into the viable but nonculturable state. J Microbiol 2004; 42(2): 69-73.

118. Xiao X., Tian C., Yu Y., Wu H. Detection of viable but nonculturable Escherichia coli 0157:H7 using propidium monoazide treatments and qPCR. Can J Microbiol 2013; 59(3): 157-163, https://doi.org/10.1139/cjm-2012-0577.

119. Nowakowska J., Oliver J.D. Resistance to environmental stresses by Vibrio vulnificus in the viable but nonculturable state. FEMS Microbiol Ecol 2013; 84(1): 213222, https://doi.org/10.1111/1574-6941.12052.

120. Troitskaia V.V., Chetina E.V., Aliapkina I.S., Litvin V.Yu., Gintsburg A.L. Non-culturable forms of Yersinia pseudotuberculosis in the soils of a natural focus of pseudotuberculosis. Zhurnal mikrobiologii epidemiologii $i$ immunobiologii 1996; 5: 13-15.

121. Litvin V.Yu., Gintsburg A.L., Pushkareva V.I., Romanova Yu.M., Boev B.V. Epidemiologicheskie aspekty ekologii bakteriy [Epidemiological aspects of the ecology of bacteria]. Moscow: Farmus-print; 1998; 229 p.

122. Barer M.R., Gribbon L.T., Harwood C.R., Nwoguh C.E. The viable but non-culturable hypothesis and medical bacteriology. Rev Med Microbiol 1993; 4(4): 183-191, https://doi.org/10.1097/00013542-199310000-00001.

123. Rivers B., Steck T.R. Viable but nonculturable uropathogenic bacteria are present in the mouse urinary tract following urinary tract infection and antibiotic therapy. Urological Research 2001; 29(1): 60-66, https://doi. org/10.1007/s002400000151.

124. Baffone W., Citterio B., Vittoria E., Casaroli A., Campana R., Falzano L., Donelli G. Retention of virulence in viable but non-culturable halophilic Vibrio spp. Int J Food Microbiol 2003; 89(1): 31-39, https://doi.org/10.1016/s01681605(03)00102-8.

125. Pienaar J.A., Singh A., Barnard T.G. The viable but non-culturable state in pathogenic Escherichia coli: a general review. Afr J Lab Med 2016; 5(1): 368, https://doi.org/10.4102/ ajlm.v5i1.368.

126. Bamford R.A., Smith A., Metz J., Glover G., Titball R.W., Pagliara S. Investigating the physiology of viable but non-culturable bacteria by microfluidics and timelapse microscopy. BMC Biol 2017; 15(1): 121, https://doi. org/10.1186/s12915-017-0465-4.

127. Potgieter M., Bester J., Kell D.B., Pretorius E. The dormant blood microbiome in chronic, inflammatory diseases. FEMS Microbiol Rev 2015; 39(4): 567-591, https://doi. org/10.1093/femsre/fuv013.

128. Del Mar Lleò M., Benedetti D., Tafi M.C., Signoretto C., Canepari P. Inhibition of the resuscitation from the viable but non-culturable state in Enterococcus faecalis. Environ Microbiol 2007; 9(9): 2313-2320, https://doi. org/10.1111/j.1462-2920.2007.01345.x.

129. Ayrapetyan M., Williams T.C., Oliver J.D. Bridging the gap between viable but non-culturable and antibiotic persistent bacteria. Trends Microbiol 2015; 23(1): 7-13, https://doi. org/10.1016/j.tim.2014.09.004.

130. Li L., Mendis N., Trigui H., Oliver J.D., Faucher S.P. The importance of the viable but non-culturable state in human bacterial pathogens. Front Microbiol 2014; 5: 258, https://doi. org/10.3389/fmicb.2014.00258.

131. Ayrapetyan M., Williams T.C., Baxter R., Oliver J.D.
Viable but nonculturable and persister cells coexist stochastically and are induced by human serum. Infect Immun 2015; 83(11): 4194-4203, https://doi.org/10.1128/ iai.00404-15.

132. Kim J.-S., Wood T.K. Tolerant, growing cells from nutrient shifts are not persister cells. mBio 2017; 8(2): e0035417, https://doi.org/10.1128/mbio.00354-17.

133. Ayrapetyan M., Williams T.C., Oliver J.D. Interspecific quorum sensing mediates the resuscitation of viable but nonculturable vibrios. Appl Environ Microbiol 2014; 80(8): 2478-2483, https://doi.org/10.1128/aem.00080-14.

134. Zhao X., Zhong J., Wei C., Lin C.-W., Ding T. Current perspectives on viable but non-culturable state in foodborne pathogens. Front Microbiol 2017; 8: 580, https://doi. org/10.3389/fmicb.2017.00580.

135. Orman M.A., Brynildsen M.P. Establishment of a method to rapidly assay bacterial persister metabolism. Antimicrob Agents Chemother 2013; 57(9): 4398-4409, https:// doi.org/10.1128/aac.00372-13.

136. Dietersdorfer E., Kirschner A., Schrammel B., Ohradanova-Repic A., Stockinger H., Sommer R., Walochnik J., Cervero-Aragó S. Starved viable but nonculturable (VBNC) Legionella strains can infect and replicate in amoebae and human macrophages. Water Res 2018; 141: 428-438, https://doi.org/10.1016/j.watres.2018.01.058.

137. Wang X., Wood T.K. Toxin-antitoxin systems influence biofilm and persister cell formation and the general stress response. Appl Environ Microbiol 2011; 77(16): 55775583, https://doi.org/10.1128/aem.05068-11.

138. Ramamurthy T., Ghosh A., Pazhani G.P., Shinoda S. Current perspectives on viable but non-culturable (VBNC) pathogenic bacteria. Front Public Health 2014; 2: 103, https:// doi.org/10.3389/fpubh.2014.00103.

139. Kuehl B., Marten S.-M., Bischoff Y., BrennerWeiß G., Obst U. MALDI-ToF mass spectrometry-multivariate data analysis as a tool for classification of reactivation and non-culturable states of bacteria. Anal Bioanal Chem 2011; 401(5): 1593-1600, https://doi.org/10.1007/s00216-0115227-5.

140. Su X., Zhang S., Mei R., Zhang Y., Hashmi M.Z., Liu J., Lin H., Ding L., Sun F. Resuscitation of viable but non-culturable bacteria to enhance the cellulose-degrading capability of bacterial community in composting. Microb Biotechnol 2018; 11(3): 527-536, https://doi.org/10.1111/17517915.13256.

141. Majeed M., Majeed S., Nagabhushanam K., Punnapuzha A., Philip S., Mundkur L. Rapid assessment of viable but non-culturable Bacillus coagulans MTCC 5856 in commercial formulations using Flow cytometry. PLOS One 2018; 13(2): e0192836, https://doi.org/10.1371/journal. pone.0192836.

142. Liu Y., Wang C., Tyrrell G., Hrudey S.E., Li X.-F. Induction of Escherichia coli O157:H7 into the viable but nonculturable state by chloraminated water and river water, and subsequent resuscitation. Environ Microbiol Rep 2009; 1(2): 155-161, https://doi.org/10.1111/j.1758-2229.2009.00024.x.

143. Pinto D., Almeida V., Almeida Santos M., Chambel L. Resuscitation of Escherichia coli VBNC cells depends on a variety of environmental or chemical stimuli. J Appl Microbiol 2011; 110(6): 1601-1611, https://doi.org/10.1111/j.13652672.2011.05016.x

144. Zeng B., Zhao G., Cao X., Yang Z., Wang C., Hou L. Formation and resuscitation of viable but nonculturable 
Salmonella typhi. Biomed Res Int 2013; 2013: 1-7, https://doi. org/10.1155/2013/907170.

145. Mukamolova G.V., Murzin A.G., Salina E.G., Demina G.R., Kell D.B., Kaprelyants A.S., Young M. Muralytic activity of Micrococcus luteus Rpf and its relationship to physiological activity in promoting bacterial growth and resuscitation. Mol Microbiol 2006; 59(1): 84-98, https://doi. org/10.1111/j.1365-2958.2005.04930.x.

146. Lennon J.T., Jones S.E. Microbial seed banks: the ecological and evolutionary implications of dormancy. Nat
Rev Microbiol 2011; 9(2): 119-130, https://doi.org/10.1038/ nrmicro2504.

147. Harms A., Fino C., Sørensen M.A., Semsey S., Gerdes K. Prophages and growth dynamics confound experimental results with antibiotic-tolerant persister cells. $\mathrm{mBio}$ 2017; 8(6): e01964-17, https://doi.org/10.1128/mbio.01964-17.

148. Nikitushkin V.D., Demina G.R., Kaprelyants A.S. Rpf proteins are the factors of reactivation of the dormant forms of actinobacteria. Biochemistry (Mosc) 2016; 81(13): 1719-1734, https://doi.org/10.1134/s0006297916130095. 